\title{
REGIONAL DIFFERENCES BETWEEN COMMUTERS IN SERBIA ON THE BEGINNING OF THE 21 ${ }^{\text {ST }}$ CENTURY
}

DOI: http://dx.doi.org/10.18509/GBP.2015.28

UDC: 332.13.9457.11),20“

\author{
Associate Prof. Dr. Tamara Lukić, \\ Dr. Bojan Đerčan, \\ Associate Prof. Dr. Milka Bubalo-Živković \\ University of Novi Sad, Faculty of Sciences, Serbia
}

\begin{abstract}
The aim of this paper is to define the characteristics of commuters in Serbia. One of the most important tasks is to determine regional differences. At the level of NUTS 2 regions, Serbia is divided into four regions. Particular attention is paid to the problems that arise in inter-census comparisons. Comparisons in the paper are made between gender commuting as well as type of settlement in which they live. In addition, the relation of the active population performing occupation and commuter pupils and students is considered. Part of the paper is devoted to commuters who are working or studying abroad. The research results are presented in tables and graphs. They point out the consequences which are frequent in this particular type of migration.
\end{abstract}

Keywords: commuters, Serbia, regions

\section{INTRODUCTION}

Daily migrations represent a special form of spatial mobility of economically active population performing an occupation, of pupils and students. The scope and directions of daily migrations are influenced by a number of demographic, socio-economic, geotransportation and other factors. The statistical monitoring of the changes in the daily migratory trends of the population of a certain area is significant for a large number of sciences, as well as for the practice of the local and regional planning and implementation of any spatial development program [9], [5].

Daily migrations may be developed in relation between the place of residence and place at close range, in other municipality or other country. One of the reasons why it would be important to follow daily migratory trends is the fact that the most of commuters are the potential permanent commuters, if they could manage to provide, in any way, minimum conditions for living in the target settlement [10]. Having into consideration that after disintegration of Socialist Federal Republic of Yugoslavia the social, business and economic plan was completely transformed [2], [11], the research was made according to data of census conducted after disintegration of SFRY, respectively, from the beginning of the $21^{\text {st }}$ century. Special attention was paid to the international daily migrations. They illustrate the characteristics of border as the conditions for life from its other side.

\section{METHODS}

This paper is the result of analyses of data received at the Statistical Office of the Republic of Serbia. Comparison of the last two censuses was difficult. The category 'unknown' which appeared during census of the year 2002 does not exist in data which refer to the 
last census from 2011. Therefore, in this work was made inter-censuses comparison only of total number of commuters, total number of commuters of the active population performing an occupation and total number of the contingent of pupils and students. They were analyzed according to the NTSJ (nomenclature of the statistic territorial units) regions which were analyzed at the level of European NUTS 2 regions. Serbia consists of the five regions (Table 1). Beside this, the comparison of mentioned levels was possible to be made according to the gender and type of settlement.

Table 1 Basic information about regions of Serbia, Source: [9], own calculation

\begin{tabular}{lrrr}
\hline \multicolumn{1}{c}{ Regions of Serbia } & Surface (\%) & Inhabitants (\%) & Settlements \\
\hline Region of Vojvodina & 24.4 & 26.7 & 467 \\
Belgrade Region & 3.7 & 23.3 & 157 \\
Region of Šumadija and Western Serbia & 29.9 & 28.0 & 2112 \\
Region of South and East Serbia & 29.7 & 22.0 & 1973 \\
Region of Kosovo and Metohija & 12.3 & No data & 1449 \\
\hline
\end{tabular}

Part of inhabitants of the Albanian nationality, from the territory of municipalities of Preševo and Bujanovac refused to be in census during the year 2011. In such way was made un incalculable damage concerning the census results for the Region of South and East of Serbia as well as the Serbia in general [8]. Beside this, the Statistical Office of the Republic of Serbia does not possess data about daily migrants for the fifth Region of the Republic of Serbia, Region of Kosovo and Metohija because of the specific political situation [6].

The explanations for differences sawn regarding research, appearance and regularity were received during communication with commuters within different settlements of Serbia. For that reason, the questions were of an open character and the answers were not predictable. Data were illustrated by drawing maps: relevant content was extracted from existing figures, in order to form the desired maps.

\section{RESULTS AND DISCUSSION}

The results will be shown through the general data about commuters, by comparison of commuters of pupils and students' population with commuters of active population performing an occupation and through the characteristics of commuters who are leaving the country every day.

\section{General data}

According to data from the last census from the year 2011, there were 901299 of commuters of active population performing an occupation or pupils in Serbia who emigrated every day. Looking per NTSJ regions, commuters are the most numerous in the region of Sumadija and Western Serbia. They make the relative majority of $46.0 \%$. Almost every fourth commuter $(23.6 \%)$ of Serbia lives in the Region of Vojvodina. Minimum share of $(16.8 \%)$ of commuters within total number of commuters of Serbia is in the Belgrade region. Its poly-functionality ensures a great number of work places in different activities but within them are concentrated a numerous educational institutions. Those advantages reduce the needs of inhabitants who live in a small space, for every day migrations.

From census in 2002 to census in 2011 at the Republic level, the number of commuters was raised to $12.0 \%$. Increase is directly in correlation to the number of commuters per 
NTSJ regions, respectively, the greatest is in the Region of Sumadija and Western Serbia $(17.5 \%)$, where it is registered the greatest absolute number of commuters. The number of commuters in Belgrade region was increased for $8.4 \%$ (Table 2). The increase in the number of commuters in Serbia is one of the ways how the population is adapting and overcoming the problems of unemployment and lack of adequate jobs in the local milieu, while at the same time, maintaining of commuting as the form of mobility that prevents further concentration of population in urban centers [3].

Commuters who live out of urban centers are more numerous from the commuters from urban centers. For example, the educational institutions (secondary schools, faculties) are in urban centers and because of them most often the pupils migrated every day. According to census in 2002, commuters of urban centers made a quarter (24.8\%) of all commuters. The greatest share of commuters from urban centers lived in Belgrade region (38.6\%) but minimum were in the Region of the South and East Serbia (17.6\%). Such result was influenced by a number of urban centers within certain region. The largest numbers of urban settlements were in Belgrade region.

Since the eighties years of the 20th century in Central Serbia, there was a trend of share increase of urban inhabitants in daily migrations, while in Vojvodina, this share was reduced, at first (1981 - 1991) but it was slightly increased (1991 - 2002) [4]. The results from the last census have shown the increase of the absolute number of daily migrants in urban centers (26.8\%) and villages (5.6\%). It means that the inhabitants in urban centers became more mobile because of the phenomenon of difficulties to find a job. The greatest change of absolute numbers of commuters who lived in urban centers was registered in the Region of Šmadija and Western Serbia (40.2\%) and the South and East Serbia (35.5\%) (Table 2). Changes of the absolute number of commuters from the other settlements came to $12.3 \%$ in the Region of Šmadija and the Western Serbia while in the Region of Vojvodina was only $0.2 \%$. Share of commuters from urban centers in total number of commuters was $29.9 \%$ according to census from 2011 which is $5.1 \%$ more, in comparison with census from 2002. This value had mostly grown in the Region of the South and East Serbia (7.1\%) (Table 2).

Looking by gender, men were mostly commuters at the Republic level, according to census in $2011(57.9 \%)$. Even in the seventies of the last century was proved that women participated less in daily migrations [5]. Number of men commuters in absolute values and at the Republic (8.3\%) and in all regions is increased, but such increase was less than increased number of daily migrants for women (16.9\%). The increased daily migration of women concerning work labor was caused by the level of activity and professional structure of women. The higher degree of women education and their mass education has reflected to increased spatial and social movables of women, so in such way changes of structure and directions (territory target) of daily migration flows [5]. The most intensive increase of the absolute number of commuters of men (13.2\%) and women (23.6\%) of inhabitants was noticed in the region of Šumadija and Western Serbia. Minimum increase of the absolute number of commuters of men inhabitants had the Region of the South and East Serbia (4.1\%) and women in Belgrade Region (10.8\%). The share of commuters of male in total number of commuters was reduced from census from 2002 till census of 2011 , that is $-2.4 \%$. This reduction was established in all regions of Serbia. The most intensive was in the Region of the South and East of Serbia (-3.6\%). It is confirmed by already mentioned conclusion about affirmation of women from this region (Table 2). 
Table 2 Number of commuters, shares of commuters in urban centers and male commuters, according to census from 2002 and 2011, Source: [9], [7], own calculation

\begin{tabular}{|c|c|c|c|c|c|c|c|c|c|}
\hline \multirow[t]{2}{*}{ Regions } & \multicolumn{3}{|c|}{ Number } & \multicolumn{3}{|c|}{$\begin{array}{c}\text { Share of town } \\
\text { commuters in total }\end{array}$} & \multicolumn{3}{|c|}{$\begin{array}{c}\text { Share of man commuters } \\
\text { in total }\end{array}$} \\
\hline & 2002 & 2011 & $\begin{array}{l}\text { Change } \\
\text { in } \%\end{array}$ & 2002 & 2011 & $\begin{array}{l}\text { Change } \\
\text { in } \%\end{array}$ & 2002 & 2011 & $\begin{array}{l}\text { Change in } \\
\%\end{array}$ \\
\hline $\begin{array}{l}\text { Region of } \\
\text { Vojvodina }\end{array}$ & 227162 & 252583 & 10.1 & 32.1 & 38.8 & 6.7 & 58.4 & 56.7 & -1.7 \\
\hline $\begin{array}{l}\text { Belgrade Region } \\
\text { Region of }\end{array}$ & 160195 & 174807 & 8.4 & 38.6 & 40.4 & 1.8 & 56.6 & 55.5 & -1.2 \\
\hline $\begin{array}{l}\text { Šmadija and } \\
\text { Western Serbia }\end{array}$ & 233227 & 282855 & 17.5 & 13.7 & 18.9 & 5.2 & 61.4 & 58.4 & -3.1 \\
\hline $\begin{array}{l}\text { Region of South } \\
\text { and East Serbia }\end{array}$ & 172933 & 191054 & 9.5 & 17.6 & 24.7 & 7.1 & 64.4 & 60.8 & -3.6 \\
\hline $\begin{array}{l}\text { Region of } \\
\text { Kosovo i } \\
\text { Metohija }\end{array}$ & $\begin{array}{l}\text { No } \\
\text { data }\end{array}$ & $\begin{array}{l}\text { No } \\
\text { data }\end{array}$ & - & $\begin{array}{l}\text { No } \\
\text { data }\end{array}$ & $\begin{array}{l}\text { No } \\
\text { data }\end{array}$ & - & $\begin{array}{l}\text { No } \\
\text { data }\end{array}$ & $\begin{array}{l}\text { No } \\
\text { data }\end{array}$ & - \\
\hline Serbia total & 793517 & 901299 & 12.0 & 24.8 & 29.9 & 5.1 & 60.2 & 57.9 & -2.4 \\
\hline
\end{tabular}

According to the settlement type, it is noticed that men make the majority of commuters as well as in the cities and other settlements. In comparison to census from the year 2002 in urban centers is increased the number male of commuters, while at the villages is reversely.

\section{Commuters of active population performing an occupation and the pupils and students}

Commuters of active population performing an occupation, according to census from the year 2002 make $71.2 \%$ of all commuters in the Republic of Serbia. Similar share was in the regions and it was from $69.6 \%$ in the Region of Šumadija and Western Serbia till $74.4 \%$ in Belgrade Region. According to census from the year 2011 the share of commuters of active population performing an occupation was reduced for about three percentages (68.3\%). This reduction was noticed in all regions, except Belgrade Region, where appeared a share increase from $74.4 \%$ to $76.1 \%$ (Map 1).

Increase of commuters of the pupils and students in the regions south from Belgrade was influenced by appearance of extinguishing of elementary and secondary school classes in settlements where there is no minimum number of pupils for the normal functioning. Beside it, weakening of the economic power, the parents were unable to pay lease of accommodation for their secondary school pupils and students, so they were forced to travel every day in different ways to their educational institutions.

The absolute numbers of commuters of the active population performing an occupation were increased to all observed levels from census of the year 2002 till census of 2011. At the Republic level this increase was $9.0 \%$, but it ranged from $2.0 \%$ in the Region of the South and East Serbia to $12.7 \%$ in the Region of Šumadija and Western Serbia. Such type of commuters of the active population performing an occupation reduction was noticed in other settlements concerning men inhabitants, especially in the Region of Vojvodina (9.2\%) and the Region of the South and Eastern Serbia (-15.3\%).

Absolute numbers of the pupil and students' population of commuters had also shown the increase. The increase almost came to the quarter level (24.9\%) at the Republic level, but in the regions goes from $2.1 \%$ in Belgrade Region to $40.9 \%$ in the Region of Sumadija and Western Serbia. Small increase in the Belgrade Region may be explained that this 
region had the greatest number of different educational institutions who existed for many years in this area. In urban settlements of the Belgrade Region is registered share fall of female commuters of the pupils and students for $-1.8 \%$, from the 2002 census to the census 2011. In the Region of Šumadija and Western Serbia, the increase of commuters of the pupil and students' population is the consequence of opening of numerous 'protruding' departments, mostly private ones of the high educational institutions.

\section{Commuters who are leaving Serbia}

Serbia as well as other the Western Balkan countries tends to be included into the European Union. Then the frontiers among the neighboring countries should not exist. Therefore the special attention is made to commuters who are going every day to the other countries looking for a job, or school. According to data from census 2011 there are such commuters of 4507. They make a half percentage of all commuters in the Republic of Serbia. From this number, relative majority $(40.5 \%)$ lives in the Region of Šumadija and Western Serbia, each third (33.3\%) is from the Region of Vojvodina while the minimum is in Belgrade region (14.6\%) and the Region of the South and East Serbia (11.6\%). Each fifth $(21.8 \%)$ of commuters in Serbia who goes abroad live in Mačva district and each the tenth $(9.8 \%)$ is from Zlatibor district (Map). Both areas are situated along the border with the Republika Srpska, i.e. Bosnia and Herzegovina. Identity card is enough to cross the border. The greatest part of the traffic structure was made during the twentieth century. The Serbs live from both sides of the border, so there is no language barrier. The appearance of commuters in the area of the Croatian border is much smaller. It differs only by the fact that instead of identity card passport is requested. In comparison with the greatest part of border area in the Republic of Croatia, the approach to the border areas is easier because of the absence of the relief obstacles and presence of dense traffic roads net. Besides that, near the borders of Croatia, less than $50 \mathrm{~km}$ from the Republic of Serbia, there are more large settlements where exist a number of educational institutions.

Great mobility of people is from Belgrade area. The research shows that distance is not a burden for residents of the capital, in comparison with residents from the other parts of Serbia. Concerning the time, sometimes it is easier to go out of Belgrade than to go from one end of town to the other.

More important numbers of commuters, who are leaving Serbia every day, have been noticed in the Region of Vojvodina, respectively, in the North of Bačka district (8.8\% of commuters of Serbia), the North Banat district (7.8\%), South Bačka district (6.5\%) and South Banat district (3.9\%). Those commuters go to Hungary or Romania. Roads, especially international highway E-75 and part of road E-70 makes transport easier. The language barriers toward those directions do not exist because it was found that regarding communication with inhabitants from those regions commuters make the groups who speak the languages of the countries where they migrate. It can be said that their language skills allow them the employment and education. Besides that, they are supported by relatives and friends who live on the other side of the border [12]. From three of commuters who left the country, men made two (63.3\%). Share of men goes from $68.6 \%$ in the Region of the South and East Serbia up to $60.5 \%$ in the Region of Vojvodina. 


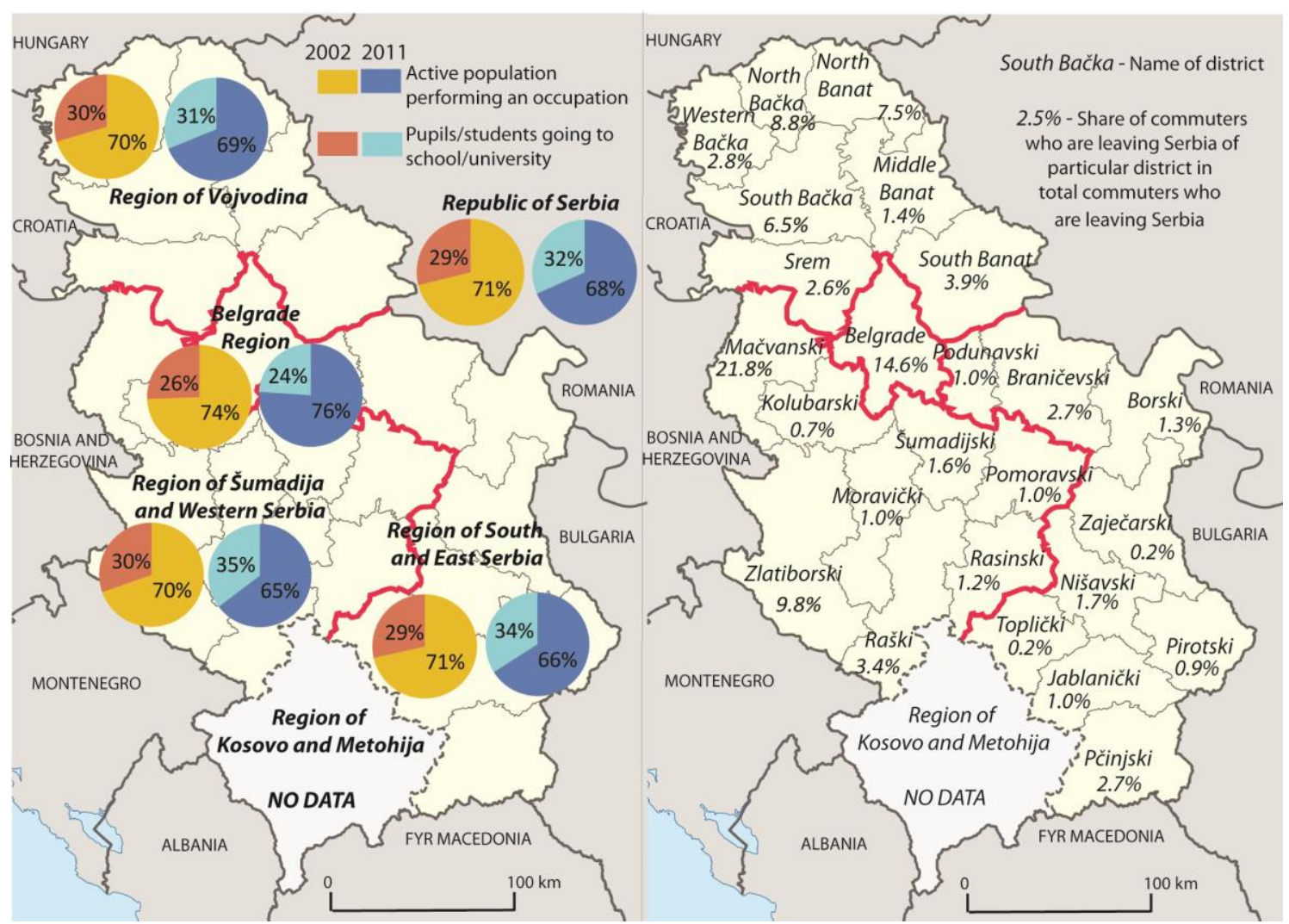

Map 1 Relation between daily migrants of active population performing an occupation and pupils and students (left side). Distribution of share of commuters who are leaving Serbia by districts (right side),

Source: [9], [7], own calculation

Concerning commuters at the Republic level, who are leaving the country prevail the pupils and students in comparison to the active population performing an occupation $(52.2 \%)$. Observed by regions, pupils and students are numerous commuters toward neighbor countries in the Region of Sumadija and Western Serbia (59.9\%) and Region of Vojvodina $(58.8 \%)$. Commuters of the active population performing an occupation prevailed in other regions. So, the share of pupils and students in the Region of the South and East Serbia make 38.9\%, but in Belgrade region it makes only 26.4\%. In some municipalities all commuters are pupils and students, such as: Bela Crkrva, Nova Crnja, Bojnik and Bujanovac. Communities where they make more than $75 \%$ are: Sjenica, Dimitrovgrad, Bosilegrad, Priboj, Alibunar, Ada, Senta, Bačka Topola, Ljubovija, Tutin. Great values of number of commuters of pupils and students in comparison to commuters of active population performing an occupation need not have great absolute values. The mentioned municipalities have the value in absolute numbers higher than 30 of commuters. There are written traces about those migration flows. Great share of pupils and students in commuters out of Serbia in the municipalities from Dimitrovgrad and Bosilegrad are explained by motivation from Bulgaria in the form of scholarship for students from Serbia [1]. Observing by gender, the male pupils and students are numerous at the Republic level (52.5\%), in the Region of the South and Eastern Serbia (61.1\%), Region of Sumadija and Western Serbia (54.9\%), while they have no majority in the Region of Vojvodina (48.4\%) and Belgrade Region (48.0\%). 


\section{CONCLUSION}

During the last decade the number of commuters was increased for $12.0 \%$. In comparison to the total number of inhabitants in Serbia, daily migrate $12.5 \%$, from their settlements in order to get a job or education.

Political situation has influenced to differences existing among the regions of the Republic of Serbia. In the region of Kosovo and Metohija census was not conducted, so the Statistical Office of the Republic of Serbia does not have data about commuters.

The policy have influenced to decision about boycott of census 2011 in municipalities at the Region of the South and East Serbia. The boycott was caused irreparable damage. The boycott will have to be mentioned in all further inter-censuses and inter-regional comparisons.

More than two fifths of commuters of Serbia live in the Region of Šumadija and Western Serbia. Significant influences to the number and characteristics of commuters have the characteristics of the region and functions of their settlements. Belgrade region is distinguished by various characteristics of commuters in comparison to the other regions of Serbia, because of the small size of the territory, small number of settlements and its multi-functionality.

By this research was confirmed that the volume and flows of daily migrations are mostly conditioned by the economic situation in the country and surroundings. The characteristics of border in the sense of existence: traffic infrastructures, administrative permeability, language barriers, policy of neighboring countries and administrative helpfulness of their inhabitants have influence to mobility of commuters from the borders' region.

\section{REFERENCES}

[1] Đorđević, D. \& Milošević Radulović, L. Pogranične opštine Jugoistočne Srbije u štampanim medijima - primer Narodnih novina, Теме - Часопис за друштвене науке, no 36, 04: 1583-1611, 2012.

[2] Filipović, M. Sustainable Development of Serbia at the Beginning of the 21 st Century. Industrija 40, no. 1: 133-148, 2012.

[3] Lukić, V. \& Tošić, B. Daily commuting-similarities and differences between Serbia and Slovenia. Geografski Zbornik/Acta Geographica Slovenica, 51, no. 2, 2011.

[4] Lukić, V. Commuting in the settlement system of Serbia. Stanovništvo 49, no. 2: 25$50,2011$.

[5] Lukić, V. Socio-economic aspects of commuting, Sociologija 55, no. 2: 283-298, 2013.

[6] Nagy, A. North Kosovo as a Political and Administrative Phenomenon. Revista de Ştiinţe Politice. Revue des Sciences Politiques, no 42: 25-33, 2014.

[7] Republički zavod za statistiku, Dnevni migranti, Podaci po opštinama, Stanovništvo, no 13, Popis stanovništva, domaćinstava i stanova u 2002. godini, Beograd, 2004.

[8] Riznić, D., Voza, D. \& Vuković, M. Пограничје источне и југоисточне Србије у штампаним медијима националног значаја. Теме - Часопис за друштвене науке, по 36, 04: 1559-1582, 2012.

[9] Statistical Office of the Republic of Serbia, Daily migrants, Data by municipalities/cities, Population, 2011, no 11, Census of Population, Households and Dwellings in the Republic of Serbia, Belgrade, 2013.

[10] Shuai, X. Does Commuting Lead to Migration? The Journal of Regional Analysis \& Policy 42, no. 3: 237, 2012. 
[11] Šabić, D, Vujadinović, S, Milinčić, M, Golić, R, Stojković, S, Joksimović, M, Filipović, D, Šećerov, V. \& Dimitrijević, D. The impact of FDI on the transitional economy in Serbia-changes and challenges. Acta Polytechnica Hungarica 9, no. 3: 6584, 2012.

[12] Takač, Z, Kinčeš, A. Migracija srpskog stanovništva u susednu Mađarsku u razdoblju pre Šengenskog sporazuma, Anali Ekonomskog fakulteta, Subotica, 2011. 